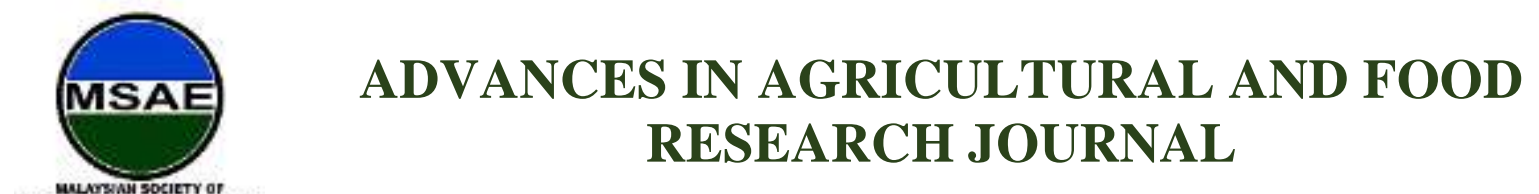

HH PUBLISHER

Original Research Article

\title{
Performance of a Triangular Rubber Tracked Tractor in Paddy Fields
}

\author{
Ahmad Mohd Taufik ${ }^{1 *}$, Khadzir Mohd Khusairy ${ }^{2}$, Omar Mohamad Fakhrul Zaman ${ }^{3}$ \\ ${ }^{1}$ Engineering Research Center, MARDI HQ, Serdang, Selangor, 43400, Malaysia. \\ ${ }^{2}$ Engineering Research Center, MARDI Seberang Perai, Penang, 1320, Malaysia. \\ ${ }^{3}$ Engineering Research Center, MARDI Seberang Perai, Penang, 06500, Malaysia. \\ *Corresponding author: Ahmad Mohd Taufik, Engineering Research Center, Mardi HQ, Serdang, Selangor, \\ 43400, Malaysia; taufik@ mardi.gov.my.
}

Abstract: Tracked tractors have been commonly used on paddy fields to overcome soft soil problem. However, triangular-shaped rubber-tracked tractors with high clearance has not been properly tested. The objective of the research was to evaluate the performance of a triangular, rubber-tracked tractor used in paddy fields. This tractor was tested in typical paddy field conditions at MARDI Seberang Perai. The prime mover was attached with a rotary tiller. The performance tests include measuring the soil bearing capacity before and after machine disturbance, machine work rate per hectare and the effective field capacity. The fuel consumption was also recorded. Results showed that the tracked tractor obtained an effective field capacity of $0.576 \mathrm{hr} / \mathrm{ha}$ with average fuel consumption of 20 liters/ha. The lightweight tractor also contributed in producing less ground effects, combined with the use of low ground contact pressure tracks, that caused minimal soil disturbance that would affect the soil hardpan layer. The tractor had enough power to move in typical paddy field condition, with no soft soil problems. The tractor was able to turn 360 degrees within a small area, which made it suitable for working in paddy fields. This prime mover has potential to be used in paddy fields.

Keywords: triangular rubber tracked tractor; low ground contact pressure; machine performance; soft soil; paddy mechanization

Received: $6^{\text {th }}$ October 2020

Accepted: $6^{\text {th }}$ November 2020

Available Online: $20^{\text {th }}$ November 2020

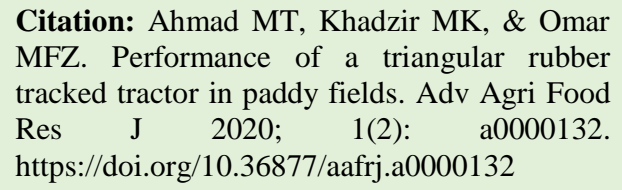

\section{Introduction}

Tractors have been used for land preparation in the Malaysian paddy production. Land preparation is fully mechanized, be it using 2-wheel or 4-wheel tractors. Omar et al. (2019) reported that there are 10,000 units of tractors used in Malaysian paddy production, with 30\% of it are 4 -wheel tractors. From this percentage, $83 \%$ is owned by private service providers while the remaining $17 \%$ is owned by government agencies. 
Although mechanization has helped increase the productivity of paddy production, it has also been blamed to cause soft soil condition. Soft soil condition is defined as a condition with high compressibility and low strength, with a hardpan layer of less than $0.3 \mathrm{MPa}$ at 30 cm soil depth (Kim, 2010; Nordin et al., 2014; Rendana et al., 2017). Soft soil condition is caused by the extensive use of heavy field machinery which damages the soil hardpan layer (Ahmad et al., 2014; Ahmad et al., 2015). The soil hardpan layer is required in paddy fields to support the weight of field machinery, other than to prevent water leakage (Hemmat \& Taki, 2003).

Soil hardpan layer damage is claimed to be caused by the usage of high ground contact pressure pneumatic rubber tyres (Vial et al., 2020). This type of tyres has small contact area to the ground surface, and when using tractors and combine harvesters with total mass of more than 5tons, hence creating big pressure to the soil surface (Taghavifar \& Mardani, 2013).

An alternative to reduce this problem is to use tracks replacing rubber pneumatic tyres. Agricultural tracks provide better traction performance and mobility, and reduces soil compaction (Fukushima et al., 2019; Zhao et al., 2020). There are several options of agricultural track configurations that are available such as full tracks, half-tracks and 4 halftracks or quad-tracks. From these configurations, there are two types of track material used, which are rubber tracks or steel tracks.

A different type of tracked tractor has been recently imported into Malaysia. This uniquely designed tractor is equipped with full tracks, except that the full tracks are triangular shaped. The oscillating crawler units is claimed to have better stability on uneven ground surface (Fukushima et al., 2019). This type of machine has not yet been fully tested scientifically and technically in Malaysian paddy fields, hence requires a specific experiment.

The objective of this paper is to evaluate the machine performance in terms of machine performance, slippage and soil bearing capacity.

\section{Materials and Methods}

\subsection{Machine Description}

The tractor is a fully tracked tractor with a power rating of $60 \mathrm{~kW}(80 \mathrm{hp})$ at a rated engine speed of $2400 \mathrm{rpm}$. The tractor is powered by a direct-injection, vertical, water-cooled, four-stroke turbodiesel engine. The tractor is $3.7 \mathrm{~m} \mathrm{long}$ and $1.65 \mathrm{~m}$ wide. The tractor is equipped with a rubber track system that is driven by a drive sprocket attached at the rear end of the chassis. The rubber track is triangular shaped with 6 rollers and two idlers. Weight ballast of $120 \mathrm{~kg}$ was attached to the front end of the tractor. The overall weight of the tractor is $2600 \mathrm{~kg}$. A rotary tiller with was attached to the tractor. The working width of the implement was $203 \mathrm{~cm}$ (80 in rotary tiller). The tillage depth was measured manually using a steel ruler from the soil surface to the tillage disturbance area. 
Table 1. Tractor specifications.

\begin{tabular}{|c|c|}
\hline Item & Description \\
\hline Brand & Wong \\
\hline Model & NF802 \\
\hline Power Rating kW (Hp) & 60 (80) at 2400 RPM Engine Speed \\
\hline Power Take-Off (PTO) speed & 720RPM at 1000 RPM Engine Speed \\
\hline Engine type & $\begin{array}{l}\text { direct-injection, vertical, water-cooled, four-stroke } \\
\text { turbodiesel }\end{array}$ \\
\hline Implement width, $\mathrm{cm}$ & 203 \\
\hline Total weight, $\mathrm{kg}$ & 2600 \\
\hline Overall length, $\mathrm{m}$ & 3.69 \\
\hline Overall width, $\mathrm{m}$ & 1.65 \\
\hline Fuel Tank Capacity, liters & 75 \\
\hline
\end{tabular}

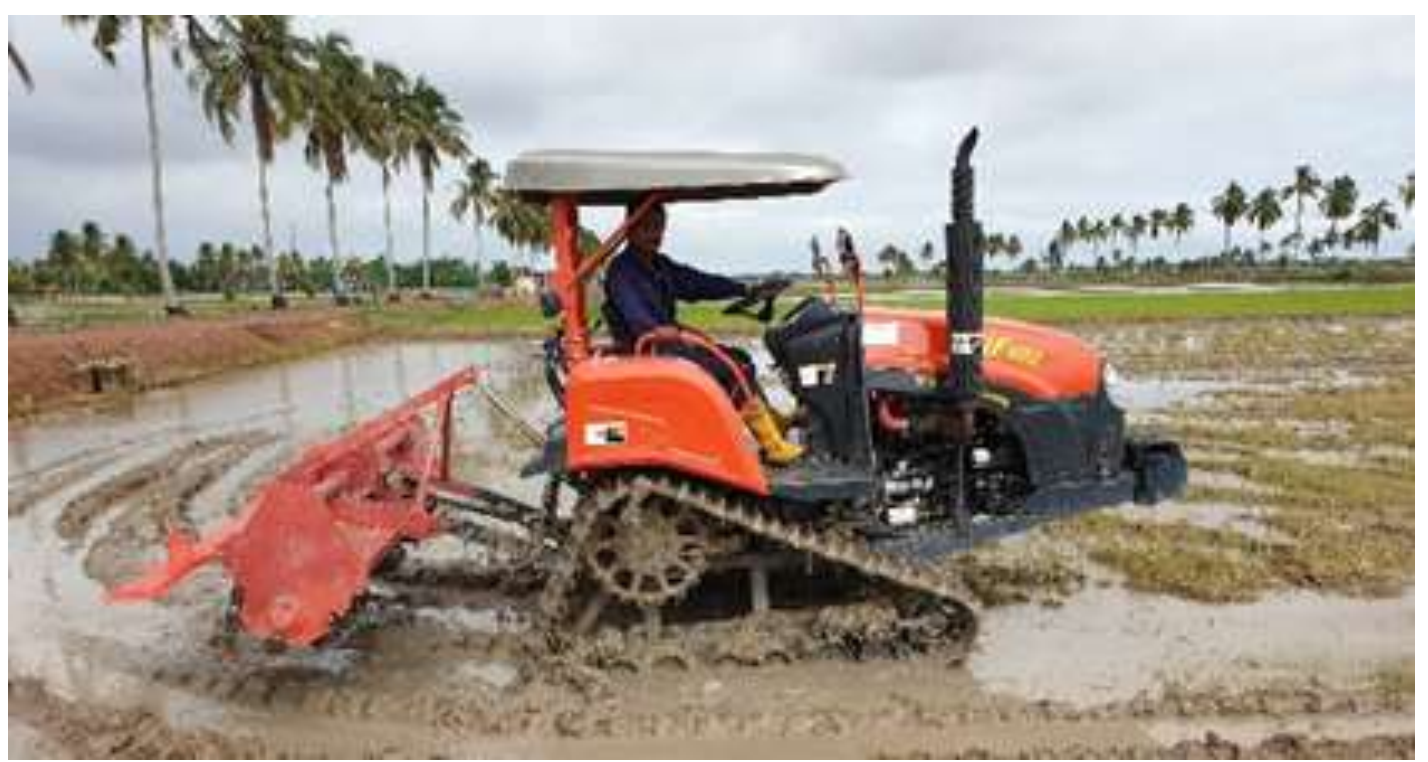

Figure 1. The triangular rubber tracked tractor attached with a rotary tiller.

\subsection{Experimental Setup}

The experiment was conducted at MARDI Seberang Perai using a paddy field area of 10 ha consisting of sandy loam soil. The type of soil and tillage depth was recorded. The test plots had no events of soft soil problem. Machine workrate per hectare was measured using a stopwatch. The effective field capacity was measured using the time consumed for real work 
and lost for other activitiies such as turning,loading or unloading and adjustment depending on field have been used.

Effective field capacity (ha/hr),

$$
\mathrm{S}=\frac{\mathrm{A}}{\mathrm{T}_{\mathrm{P}}}+\mathrm{T}_{1}
$$

where

$\mathrm{A}=$ Area covered (ha)

$\mathrm{T}_{\mathrm{p}}=$ Productive time $(\mathrm{hr})$

$\mathrm{T}_{1}=$ Non-productive time $(\mathrm{hr})$

The fuel consumption was measured by filling up full tank of the tractor before tillage work. After completing a number of hectares, amount of fuel used was measured by how much fuel is refilled into the tank. The amount of fuel used in liters, divided by the number of hectares covered, gives the fuel consumption in litre per hectares (1/ha).

Slippage, or wheel slip can be defined as the ratio between the actual travel speed of the vehicle and the theoretical travel speed of its wheel. The theoretical speed of the wheel was measured by measuring the distance of the wheel when rotating for a number of ten revolutions on tarmac. This value was then compared with the actual travel speed, by measuring the distance of the wheel after rotating ten revolutions on paddy soil.

Soil conditions were evaluated by the soil penetration or soil compaction. Readings of soil compaction were taken before and after the passage of the tractor, at the beginning, halfway, and at the end of the test area, with 3 replicates for each sampling area. Two types of soil compaction data were taken, which were soil compaction after passage of tractors' tracks and no disturbance which acted as the control data. The soil strength was measured up to 80 cm depth using a soil cone penetrometer (Penetrologger, Eijkelkamp, The Netherlands) with a base area of $323 \mathrm{~mm}^{2}$ (ASABE, 2009). Tracks soil disturbance data was taken. No disturbance data was also taken as control. The machine sinkage was also measured. The results from the soil compaction were analyzed using ANOVA (SAS, 2015).

\section{Results and Discussions}

\subsection{Machine Performance}

Table 1 shows the results obtained from the experiment. The tillage depth was roughly $40 \mathrm{~cm}$ using the full working width of the implement, $203 \mathrm{~cm}$. The measured effective field capacity using this tractor was 0.576 hour/hectares, which is considered fast if compared to most rear half-tracked tractors that are commonly used. The use of a wide rotary tiller showed effectiveness of the tillage work. The fuel consumption is average, using 20 liters for one 
hectare of land. This is mainly caused by the machine operated by MARDI operators and the soil condition of the experimental plot. Better fuel consumption is expected, done by a skilled and experienced operator with better soil conditions, at a range of 10-15 liters per hectare in typical paddy field conditions.

Table 2. The summary results for machine performance.

\begin{tabular}{cc}
\hline Performance Evaluation & Results \\
\hline Tillage depth $(\mathrm{cm})$ & 40 \\
Working width $(\mathrm{cm})$ & 203 \\
Effective field capacity $(\mathrm{hr} / \mathrm{ha})$ & 0.576 \\
Fuel consumption $(\mathrm{l} / \mathrm{ha})$ & 20 \\
\hline
\end{tabular}

\subsection{Slippage}

Slippage is important in assessing the tractive efficiency and optimal settings of a prime mover. Slippage is used as an indicator to determine the correct tractor weight ballast and operating speed, which can result in not only efficient performance, but also fuel efficient. The slippage of between $3-5 \%$ is targeted. It was observed that the slippage on farm roads is $4.25 \%$. In paddy fields, without the implement, the slippage is still within the targeted range, $4.15 \%$. However, when fixed on the rotary tiller, the slippage dropped to $2.39 \%$. Although not within the targeted range, the quality of tillage is excellent. The operation was smooth and easy to handle by the operator. During operation, there were times when the front end of the tractor was tilted upwards. Although this does not affect the performance of the tillage, but it might cause visibility and handling problems to the operator. This can be solved by installing enough ballast when more draught force is required.

Table 3. The summary for slippage.

\begin{tabular}{cc}
\hline Condition & $\begin{array}{c}\text { Slippage, \% (Standard } \\
\text { Deviation) }\end{array}$ \\
\hline Farm Road & $4.25(1.5)$ \\
Paddy field (without rotary tiller) & $2.39(2.3)$ \\
Paddy field (with rotary tiller) & $4.15(2.5)$ \\
\hline
\end{tabular}

\subsection{Soil Bearing Capacity}

The soil effects after tractor disturbance was not significant $(t=0.30, p=0.763)$. This showed that the low ground contact pressure of the tracked tractor has minimal effect on typical paddy fields. Although the working depth of the machine is $40 \mathrm{~cm}$, the graph shows that there is no significant damage to the soil strength at $0-40 \mathrm{~cm}$. This tractor will be useful 
for fields that are currently without any soft soil condition, as results here show no significant effects.

Figure 2. Soil penetration resistance of machine before and after disturbance.

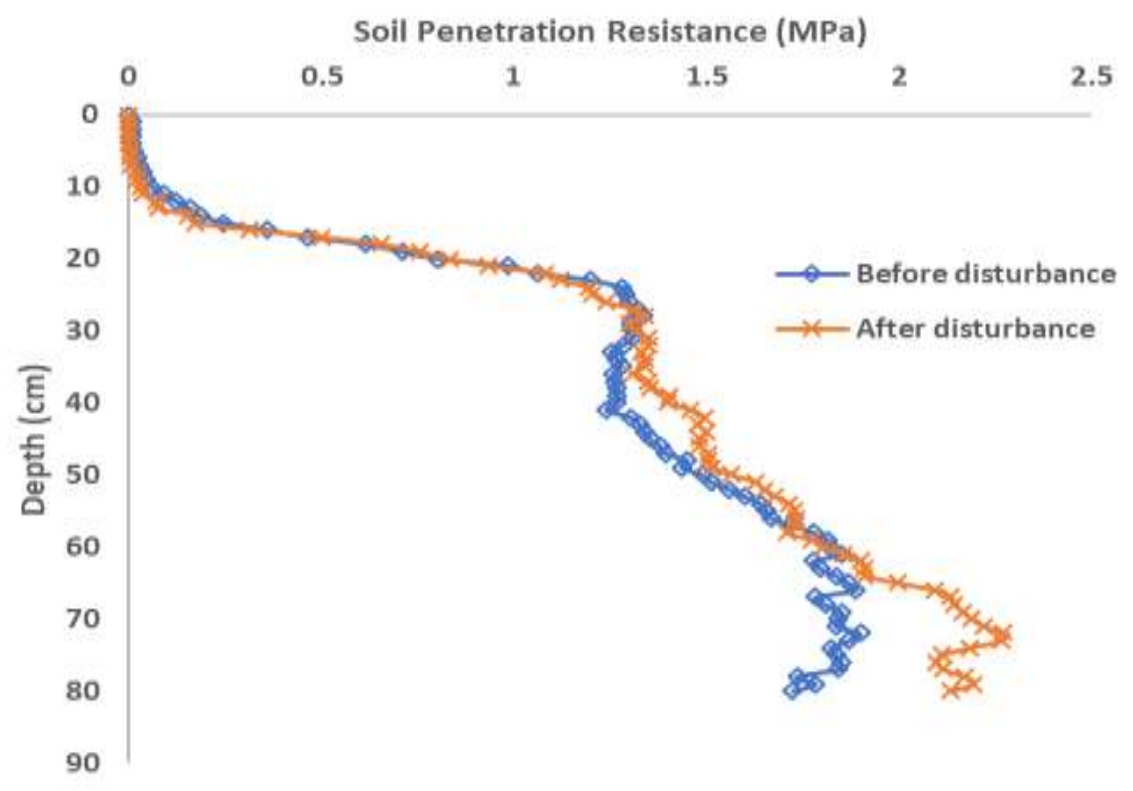

\section{Conclusions}

The tracked tractor was tested in typical tillage conditions on paddy fields. The tracked tractor showed impressive results, obtaining an effective field capacity of $0.576 \mathrm{hr} / \mathrm{ha}$ with average fuel consumption of 20 liters/ha. Feedbacks from tractor operator were positive, although the tractor requires some training to operate, due to the use of tracks instead of wheels. Maneuverability of the tractor was excellent, able to turn 360 degrees within a small area, which makes it perfect for paddy field cultivation. The tractor had enough power to move in typical paddy field condition, with no soft soil problems. The low weight of the tractor also contributes in producing less ground effects, combining with the use of low ground contact pressure tracks. This prime mover has potential to be used in paddy fields.

Author Contributions: Investigation, M.K. Khadzir, M.T. Ahmad; resources, M.K. Khadzir; writing-original draft preparation, writing — review and editing, M.T. Ahmad, M.K. Khadzir, M.F.Z. Omar.;

Acknowledgments: The researchers would like to express gratitude to Wong Engineering Sdn Bhd for providing one unit of NF802 for the duration of the experiment. The researchers would also like to thank the Engineering Research Center staffs from MARDI Seberang Perai for their assistance throughout the experiment.

Conflicts of Interest: The authors declare no conflict of interest. 


\section{References}

Ahmad, M. T., Khadzir, M. K., Mohamed Isa, F., et al. (2014). Preliminary trial of a quad-steel tracked tractor on paddy field. Proceedings of National Conference on Agricultural and Food Mechanization, 130133.

Ahmad M. T., Khadzir M. K., Md Isa M. F., et al. (2015). Performance of a Quad-Steel Tracked Tractor on Paddy Field. Proceedings of Malaysian Soil Science Conference. Malaysian Soil Science Society $(M S S S)$.

ASABE. (2009). Soil Cone Penetrometer. In ASABE Standards.

Fukushima, T., Katagiri, H., Mitsuoka, M., et al. (2019). Proposal of a measurement method for the tension of crawlers' rubber tracks by using their inner structure. Engineering in Agriculture, Environment and Food. https://doi.org/10.1016/j.eaef.2019.12.010

Hemmat A., \& Taki O. (2003). Comparison of compaction and puddling as pre-planting soil preparation for mechanized rice transplanting in very gravelly Calcisols in central Iran. Soil and Tillage Research, $70(1), 65-72$.

Kim, H. B. (2010). Problematic soils in search for solution. UPM Press. UPM Press. https://doi.org/10.1201/9781315380643-9

Nordin M. N., Hamid A. A., Sharu E. H., et al. (2014). Kaedah penggantian tanah untuk meningkatkan kekuatan struktur tanah di kawasan tanah jerlus. Jurnal Teknologi, 70(6), 45-47. https://doi.org/10.11113/jt.v70.3536

Omar S. C., Shaharudin A., \& Tumin S. A. (2019). The Status of the Paddy and Rice Industry in Malaysia. In Khazanah Research Institute. Kuala Lumpur.

Rendana M., Idris W. M. R., Rahman Z. A., et al. (2017). Effect of hasil tani organic compound product (HTOC) on the recovery of soft soil in rice field Mada Alor Senibong, Kedah, Malaysia. Asian Journal of Environment, History and Heritage, 1(2), 13-20.

Taghavifar H., \& Mardani A. (2013). Potential of functional image processing technique for the measurements of contact area and contact pressure of a radial ply tire in a soil bin testing facility. Measurement: Journal of the International Measurement Confederation, 46(10), 4038-4044. https://doi.org/10.1016/j.measurement.2013.07.019

Vial L. K., Molesworth A., \& Lefroy R. D. B. (2020). Balancing rice and non-rice crops: Managing the risks from soil constraints in Mainland Southeast Asian rice systems. Field Crops Research, 246, 1-17. https://doi.org/10.1016/j.fcr.2019.107677

Zhao Z., Mu X., \& Du F. (2020). Constitutive model research for rubber-cord composites used in rubber track. Materials Today Communications, 23, 1-7. https://doi.org/10.1016/j.mtcomm.2020.100937

Copyright (C 2020 by Ahmad MT et al. and HH Publisher. This work is licensed under the Creative Commons

Attribution-NonCommercial 4.0 International Lisence (CC-BY-NC4.0) 